\title{
A LITERATURA JUVENIL ATINGE OS HORIZONTES DE EXPECTATIVAS DOS LEITORES CONTEMPORÂNEOS?
}

\author{
DOES YOUTH LITERATURE REACH THE HORIZONS OF EXPECTATIONS OF \\ CONTEMPORARY READERS?
}

\author{
¿LA LITERATURA JUVENIL ALCANZA LOS HORIZONTES DE EXPECTATIVAS DE LOS \\ LECTORES CONTEMPORÁNEOS?
}

\author{
Adriane Ester Hoffmann ${ }^{1}$ \\ Elisângela Bertolotti2
}

\begin{abstract}
RESUMO
O presente estudo evidencia a literatura juvenil e os leitores contemporâneos. Para efetivar essa relação, discutiu-se em que medida a estética da recepção auxilia para ressignificar o texto. Com essa propositiva, objetivou-se discorrer sobre a literatura juvenil, os leitores contemporâneos e a estética da recepção como uma possibilidade de auxílio à analise textual. Assim, o arcabouço teórico deste trabalho está pautado nos pressupostos dos autores Colomer (2003), Cosson (2006, 2014), Santaella $(2013,2015)$, Jauss (1994, 1989), Gadamer (1989), Iser (1979) e Dalcastagnè (2012). A partir disso, a escolha pela obra Ardente Amor \& outras histórias, mais especificamente pelo conto "Ardente Amor", de Roberto Bittencourt Martins, publicado em 1997, foi feita na tentativa de explicitar se o leitor é instigado a interagir com a trama literária. Assim, ratifica-se que este trabalho consiste na construção de uma relação significativa entre leitor e texto, cujo diálogo permite novas concepções de sentido. Também, que na contemporaneidade, a literatura juvenil enuncia-se heterogênea, apresentando novas vozes, o que proporciona ao leitor mais atitude diante da leitura.
\end{abstract}

Palavras-chave: Literatura juvenil. Leitores contemporâneos. Estética da recepção.

\begin{abstract}
This study highlights youth literature and contemporary readers. To make this relationship effective, the extent to which reception aesthetics helps to give new meaning to the text was discussed. With this proposition, the objective was to discuss youth literature, contemporary readers and the aesthetics of reception as a possibility to aid textual analysis. Thus, the theoretical framework of this work is based on the assumptions of the authors Colomer (2003), Cosson $(2006,2014)$, Santaella $(2013,2015)$, Jauss (1994, 1989), Gadamer (1989), Iser (1979) and Dalcastagnè (2012). Based on this, the choice for the work Ardente Amor \& other stories, more specifically for the short story "Ardente Amor", by Roberto Bittencourt Martins, published in 1997, was made in an attempt to clarify whether the reader is instigated to interact with the literary plot. Thus, it is confirmed that this work consists in the construction of a significant relationship between reader and text, whose dialogue allows for new conceptions of meaning. Also, that in contemporaneity, youth literature is heterogeneous, presenting new voices, which gives the reader more attitude towards reading.
\end{abstract}

Keywords: Youth literature. Contemporary readers. Reception aesthetics

\section{RESUMEN}

Este estudio destaca la literatura juvenil y los lectores contemporáneos. Para hacer efectiva esta relación, se discutió hasta qué punto la estética de la recepción ayuda a dar un nuevo significado al texto. Con esta propuesta, el objetivo fue discutir la literatura juvenil, los lectores contemporáneos y la estética de la recepción como una posibilidad de ayuda al análisis textual. Así, el marco teórico de este trabajo se basa

1 Doutora em Letras (UPF/RS). E-mail: adriane@uri.edu.br

2 Doutoranda em Educação (URI/FW). E-mail: elisangelabertolotti@gmail.com

Revista de Ciências Humanas, Frederico Westphalen - RS, v. 22, n.2, p. 96-115, maio/ago. 2021. 
en los supuestos de los autores Colomer (2003), Cosson (2006, 2014), Santaella (2013, 2015), Jauss (1994, 1989), Gadamer (1989), Iser (1979). ) y Dalcastagnè (2012). Con base en esto, la elección de la obra Ardente Amor y otros cuentos, más específicamente por el cuento "Ardente Amor", de Roberto Bittencourt Martins, publicado en 1997, se hizo en un intento de aclarar si el lector está instigado a interactuar con la trama literaria. Así, se constata que este trabajo consiste en la construcción de una relación significativa entre lector y texto, cuyo diálogo permite nuevas concepciones de significado. Asimismo, que en la contemporaneidad, la literatura juvenil es heterogénea, presenta nuevas voces, lo que le da al lector una mayor actitud hacia la lectura.

Palablas chaves: Lliteratura juvenil. Lectores contemporâneos. Estética de recepción.

\section{INTRODUÇÃO}

A literatura juvenil sofre modificações, com o passar dos anos, assim como seus leitores. A contemporaneidade apresenta-se como um desafio para que a leitura continue sendo significativa às pessoas, tendo em vista toda a tecnologia que está à disposição de todos, em todas as faixas etárias, reatualizando-se. Para efetivar essa relação, discutiu-se em que medida a estética da recepção auxilia para ressignificar o texto. Com essa propositiva, objetivou-se, neste texto, discorrer sobre a literatura juvenil, os leitores contemporâneos e a estética da recepção como uma possibilidade de auxílio à analise textual.

Nesse viés, este trabalho tem o intuito de analisar o conto "Ardente Amor", de Roberto Bittencourt Martins, publicado em 1997 na obra Ardente Amor \& outras histórias ${ }^{3}$, para explicitar se o leitor é instigado a interagir com a trama literária, diante de sua constituição estética, temática e contextualizadora. Ademais, ratifica-se que este trabalho consiste na construção de uma relação significativa entre leitor e texto, cujo diálogo permite novas concepções de sentido.

Para isso, o arcabouço teórico deste trabalho está pautado nos pressupostos dos autores Colomer (2003), Cosson (2006, 2014), Santaella (2013, 2015), Jauss (1994, 1989), Gadamer (1989), Iser (1979) e Dalcastagnè (2012). Cada um deles com suas teorias que demonstram a evolução do livro e da leitura no decorrer do tempo; também, como a literatura se adapta a essa nova perspectiva de acesso à obra e de interesse dos leitores; e, como a estética da recepção auxilia na exploração do texto e dá conta de atingir os horizontes de expectativas de seus leitores.

Reforça-se, também, neste estudo, que a Estética da Recepção considera as obras como um sistema delineado por produção, recepção e comunicação, construindo uma conexão dialética entre autor, obra e leitor. Interessa-se pelas atribuições de sentidos que uma obra tem, isto é, observa as condições sócio-históricas que contribuíram para as diversas interpretações.

\footnotetext{
${ }^{3}$ A obra escrita por Bittencourt é composta por 3 contos, "Ardente amor, "Declaração na delegacia das mulheres" e "Dentro de um formigueiro pequeno", ambas expondo uma das peculiaridades do autor, o cenário de sua origem, 0 estado do Rio Grande do Sul, mais precisamente a cidade de Bagé.

Revista de Ciências Humanas, Frederico Westphalen - RS, v. 22, n.2, p. 96-115, maio/ago. 2021. 
Dessa forma, enfatiza que os discursos adquiridos em cada processo de significação, derivam de um modo de recepção que é moldado conforme determinados sentidos históricos.

\section{O LEITOR JUVENIL CONTEMPORÂNEO}

Os livros de literatura infantil e juvenil, enquanto fenômenos culturais, têm sua origem no século XVIII. Colomer (2003) afirma que foi com as bibliotecas que a leitura fortaleceu-se como ato livre. Isso, porque as escolas sempre estiveram ancoradas em leituras de cânones da literatura adulta. As bibliotecas disponibilizavam o acesso às obras de ficção que eram lidas por prazer e não por obrigatoriedade. Essa consciência foi se ampliando, assim como houve crescimento editorial.

Colomer (2003) destaca que, ao longo da história, as definições de literatura infantil e juvenil abordam diferentes discussões. Uma, refere-se ao que se considera literário; a segunda, se há qualidade literária nas obras infantis e juvenis; e, a terceira, apresenta-se um campo literário específico à faixa etária. Colomer (2003) ressalta que foi o desenvolvimento de uma ciência literária que definiu o conceito de literariedade. Com isso, o objeto literário começou a ser visto pela sua função poética, pela sua linguagem e suas nuances linguísticas específicas.

A partir disso corrobora-se que a história do livro e da leitura tem despertado interesse de pesquisadores há muito tempo e está acirrado nesse momento que surgem novos suportes e novas estruturas para o texto escrito. Também, pelo surgimento da estrutura de hipermídia, proliferada pela internet e demais redes de comunicação. Esse fato propicia dúvidas em relação à permanência (ou não) do livro impresso. Santaella (2015) expõe essa preocupação e destaca que o livro surgiu para ser instaurador de formas de cultura. Por isso, é importante resgatar "a história do livro e seus suportes, dos leitores e suas práticas, numa busca de determinações passadas que possam ajudar a compreender os vetores do presente" (SANTELLA, 2015, p. 16).

Destaca a importância de conhecer e entender as novas formas de percepção e cognição que estão surgindo para o livro, diante de suportes eletrônicos e de estruturas híbridas. Ainda, para entender essa evolução, ressalta a relevância de se conceber que há novos leitores de livros impressos, de imagens e de formas híbridas de signos. Com isso, a autora delineia 0 perfil cognitivo do novo leitor e amplia a concepção de prática da leitura.

Assim, o livro impresso, com reproduções rápidas e fáceis, era fabricado em grandes quantidades e facilitava a meditação individual. Surgiram, então, maneiras específicas de ler 0 livro: parágrafos, alíneas, capítulos e formas para fragmentar a leitura em unidades separadas. Desde o século XVI surgiram as séries e/ou coleções, que eram multiplicadas. No entanto, foi no 
final do século XIX e início do XX que houve a proliferação dos livros pelo surgimento dos de bolso e leituras em voz alta e em silêncio são formas de demonstrar a maneira contemporânea de ler. Assim, existem leituras intensivas e extensivas, eruditas e vacilantes, como intelecção abstrata e leitura como engajamento do corpo.

Santaella (2015, p. 23), ao delinear o perfil cognitivo do leitor do livro, afirma que, a partir do século $\mathrm{XVI}$, surgiram

\begin{abstract}
a leitura individual, solitária, de foro privado, silenciosa, leitura de numerosos textos, lidos em uma relação de intimidade, silenciosa e individualmente; leitura laicizada em que ocasiões de ler foram cada vez mais se emancipando das celebrações religiosas, eclesiásticas ou familiares.
\end{abstract}

Santaella (2015) ressalta que esse tipo de leitura surge da relação de intimidade entre leitor e livro e é realizado em bibliotecas, espaço de recolhimento, longe de divertimento mundano. É contemplativa, em que o leitor pode folhear páginas em ritmo individual e de forma concentrada. Nesse sentido, o leitor contemplativo tem diante de si objetos duráveis, que pode ser consultado, revisitado sempre que o leitor quiser ou necessitar.

O leitor movente, fragmentado, surgiu após a Revolução Industrial. Isso, porque foram instituídos: telégrafo, telefone, redes de opinião, jornais. As cidades se modernizaram, a luz elétrica iluminou as metrópoles, o consumo e a moda estabeleceram uma nova identidade ao homem moderno. Diante disso, as pessoas que passeiam por essas inovações têm um olhar contemplativo, por perceber que tudo está se transformando em mercadoria. A publicidade surgiu para corroborar tal concepção e proliferar imagens e mensagens visuais.

Assim, as imagens transformadas em publicidade, cinema, fotografia, auxiliaram na agilidade do cidadão moderno, mas, em contrapartida, surgiu a fugacidade dos contatos sociais e as coisas fragmentaram-se "sob o efeito do transitório, do excessivo e da instabilidade" (SANTAELLA, 2015, p. 29). Ainda, surgiram as tensões nervosas, a velocidade, 0 superficialismo, a efemeridade, o que aumentou a vida solitária do homem moderno.

Esse segundo tipo de leitor surge com o advento do jornal e dos centros urbanos e precisa se adaptar às mudanças. Suas percepções são instáveis, fugazes e de intensidades diferentes. É um leitor "apressado de linguagens efêmeras, híbridas, misturadas" (SANTAELLA, 2015 , p. 29). Tais características, advindas do jornal, geraram linguagem híbrida e transformaram o leitor em testemunha do cotidiano. Com isso, por sua memória ser curta, ágil, por ele estar atrás de notícias, tornou-se um leitor de fragmentos.

Assim, o leitor movente é o leitor que está envolto em "formas, volumes, massas, interações de forças, movimentos; leitor de direções, traços, cores; leitor de luzes que se 
acendem e se apagam" (SANTAELLA, 2015, p. 30). Esse leitor tem outro ritmo de vida, está sincronizado com as acelerações do mundo e contata com múltiplas linguagens.

O leitor imersivo, virtual, surgiu na era digital, na entrada do século XXI. Seu suporte é a multimídia e sua linguagem é a da hipermídia. Diferente dos outros leitores, esse tem a tela diante de si, que se movimenta verticalmente e possui liberdade entre nexos, direções e rotas. Santaella (2015) ressalta que é um modo novo de ler, em que o leitor navega em uma tela, programa leituras e precisa cuidar para não se perder no percurso da rota desejada. Isso, devido ao fato de ele ter diante de si um "roteiro multilinear, multissequencial e labiríntico" (SANTAELLA, 2015, p. 33). É o leitor que interage entre nós, palavras, imagens, documentações, vídeos e todas as possibilidades de linguagens. Esse universo é novo e precisa ser compreendido tanto em transformações sensório-perceptivas quanto em mudanças físicomentais desse novo leitor, que constrói roteiros não lineares e não sequenciais.

A autora destaca a importância de se entender o funcionamento e as influências que 0 ambiente do ciberespaço possui sobre o leitor imersivo. Inicia, expondo que os processos de comunicação são criados e distribuídos digitalmente, por meio da conexão em rede. Apresenta 0 conceito de ciberespaço como "realidade multidirecional, artificial ou virtual incorporada a uma rede global, sustentada por computadores que funcionam como meios de geração e acesso" (SANTAELLA, 2015, p. 40). Complementa que o ciberespaço tem a capacidade de reunir e concentrar meios de comunicação múltiplos e interfaces gráficas dos usuários. Por isso, é considerado um mundo virtual global coerente e independente.

A evolução do ciberespaço proporcionou o surgimento de comunidades virtuais que estão construindo uma nova forma de cultura, a cibercultura. Também, esse espaço informacional, multidimensional permite que o usuário, ao acessá-lo, possa manipular, transformar e intercambiar informações. Essa imersão aprofunda-se à medida que o usuário navegar em bases de dados, em imagens animadas, em simulações virtuais do mundo físico e em controles telerrobóticos. Em esse universo da navegação, está o leitor imersivo que desenvolve disposições e competências para navegar em dados informacionais híbridos.

Tal navegação exige que o leitor imersivo compreenda as características da linguagem hipermídia. Um dos traços distintivos é a hibridização de linguagens. Os processos sígnios, códigos e mídias são acionados pela hipermídia no momento em que o leitor imersivo interage com ela e coopera para sua realização. Essa convergência das mídias "mescla textos, imagens fixas e animadas, vídeos, sons, ruídos em um todo complexo" (SANTAELLA, 2015, p. 48). A autora acredita que isso realmente vai se efetivar quando setores tecnológicos estiverem todos convergentes em um único aparelho: televisão, computador pessoal, máquinas de jogos, etc.. No 
entanto, admite que a hibridização já acontece, pois existem rádios e jornais digitais que efetivam a linguagem híbrida.

O segundo traço definidor é a capacidade que a linguagem hipermídia tem em "armazenar informação e, por meio da interação do receptor, transmutar-se em incontáveis versões virtuais que vão brotando na medida mesma em que o receptor se coloca em posição de co-autor" (SANTAELLA, 2015, p. 49). Com essa estrutura não sequencial e multidimensional, o leitor imersivo tem a possibilidade de compreender o hipertexto, que é repleto de nós e nexos associativos ou conexões. 0 entendimento diz respeito à conexão que, realizada entre esses nós, com o auxílio do mouse, permite ao leitor mover-se no hipertexto e construir a sua própria rede cognitiva.

O terceiro traço que define a hipermídia é o seu cartograma navegacional. A autora acredita que a alguns anos, esses programas de buscas estarão à disposição de todos e auxiliarão, cada vez mais, o usuário a filtrar o que deseja receber e/ou pesquisar e a ter acesso a programas que funcionam como "agentes que buscam informações na rede e avatares que permitem a construção de imagens do usuário que interagem com outros avatares" (SANTAELLA, 2015, p. 52). Isso implica afirmar que, para auxiliar usuários a não realizarem saltos por milhões de documentos, há portais que ajudam na seleção de conteúdos de acordo com o que o usuário deseja.

O quarto traço definidor é o de que a hipermídia possui uma linguagem eminentemente interativa. O leitor ao final de cada página define que rumo seguir, que informação deseja obter, o tempo destinado a cada tela e a sequência que pretende percorrer. A interatividade faz com que o leitor experiencie a imersão e, com ela, exercite a concentração, a atenção e a compreensão da informação. Assim, pelo caráter interativo, o leitor imersivo está em constante contato com a linguagem hipermidiática e hipertextual.

Santaella (2015) após definir três tipos de leitores, delineia traços definidores de um novo modo de ler dos cibernautas. Com isso, apresenta mudanças na forma de leitura do ciberespaço e expõe características de três usuários: o novato, o leigo e o experto. Um não tem nenhuma intimidade com a rede; o outro sabe entrar na rede e realiza algumas rotas, mas se limita a fazer sempre as mesmas coisas: bate-papos e e-mails; o terceiro conhece os segredos dos sinais, tem competência para encontrar o que busca com grande velocidade e possui modo próprio de navegar.

Em uma análise cognitivista, esses três tipos de usuários possuem traços gerais que dizem respeito ao modo de encontrar um caminho na hipermídia e na rede. Para que a navegação aconteça de forma eficaz, é necessário que os usuários sigam uma sequência de 
passos corretos, e, caso não sejam corretos, consigam corrigi-los, Santaella (2015) estabelece cinco etapas: estado inicial, conjunto de operadores de navegação, compreensão dos operadores, manipulação dos operadores e mudança de estados como resultado da manipulação dos operadores.

Assim, a navegação efetiva-se quando o usuário escolher algum operador (palavra, ícone, índice, barra e/ou diagrama) como indicador de sua ação em busca de um resultado esperado. Esse processo demanda da compreensão e da busca. Compreensão do estado de coisas e busca de como chegar ao alvo. A compreensão é característica do usuário novato, enquanto a estratégia de busca diz respeito ao leigo. A autora destaca que esses dois processos estão interligados, pois é imprescindível alguma compreensão para que a busca seja iniciada. No entanto, ressalta que não é preciso que uma se complete para iniciar a outra, elas acontecem concomitantemente.

O usuário experto domina esses procedimentos e substitui-os pelo reconhecimento instantâneo, que é o processo de elaboração. Nesse caminho há a internalização de um esquema geral de navegação que o caracteriza como possuidor de estratégias globais precisas e como detentor de conhecimentos do conjunto. Santaella (2015) destaca que nos três tipos de usuários, há a presença de insight. Isso significa que cada um tem a capacidade de mudar de estado, descobrir uma rota eficaz no caminho e chegar a um resultado final. Também, que a prática da navegação e os conhecimentos adquiridos podem ser atingidos por cada um dos tipos de usuários, basta que a prática seja executada para o desempenho aperfeiçoar-se.

Santaella (2015) destaca que os processos de navegação realizados pelos três tipos de usuários, após uma pesquisa realizada pela autora, revelaram que os internautas também têm características distintas: um é internauta errante: pratica a arte da adivinhação; o outro é internauta detetive: segue pistas e aprende com a experiência; e o terceiro é internauta previdente: sabe antecipar as consequências de suas ações. Especifica, porém, que apesar de classificar os internautas, cada uma dessas modalidades não exclui a outra.

Santaella (2015) afirma que com o avanço da tecnologia e o surgimento das grandes cidades, o conceito de leitura ampliou-se e que 0 ato de ler, na atualidade, alia palavra e imagem, texto e diagramação. Com essa modificação, surgiu uma multiplicidade de leitores. A autora expõe que há leitores de imagem, de jornal, da cidade, espectador, de texto escrito e de telas eletrônicas. O desafio, segundo Santaella (2015), é identificar características perceptivocognitivas dessa diversidade de leitores.

A partir da generalização, delineia três tipos principais: o contemplativo, o movente e 0 imersivo. Ressalta, no entanto, que embora haja uma sequencialidade histórica para 0 Revista de Ciências Humanas, Frederico Westphalen - RS, v. 22, n.2, p. 96-115, maio/ago. 2021. 
surgimento de cada um dos tipos de leitores, não há a exclusão de um quando do aparecimento de outro. Ainda, afirma que o leitor pode acumular características de cada um dos tipos, de forma recíproca.

Ao definir o leitor contemplativo, que também é meditativo, Santaella (2015) retoma aspectos históricos e afirma que até o século XII o monopólio da cultura livresca e da produção dos livros era dos mosteiros e de outros estabelecimentos eclesiásticos. A partir disso, com a fundação de universidades, o surgimento de uma classe burguesa e o desenvolvimento da instrução aos leigos aconteceram modificações intelectuais e sociais. Em vista disso, em bibliotecas eram obrigatório o silêncio. O leitor, então, realizava leituras silenciosas e desenvolvia um vínculo com o livro, o que permitiu que pudesse avançar em suas escolhas, de textos mais simples aos mais complexos.

Santaella (2013) amplia seus estudos e identifica outro tipo de leitor, o ubíquo, que é capaz de realizar multitarefas, pois responde à pluralidade de estímulos em um ambiente informacional complexo. Ele também reúne em si os perfis cognitivos dos leitores que 0 precederam. Dessa forma, o desafio educacional é hoje maior, porque é preciso considerar a hipercomplexidade contemporânea, em que o leitor híbrido tem na ubiqüidade de sua potência coadjuvante.

Outro estudioso da leitura e de como elas deveria ser abordada e explorada, é Cosson (2006), que dá destaque à literatura que está sendo estudada na escola e afirma que ela está enfrentado momentos conflitosos. Mantém-se, ainda, por força da tradição e da inércia curricular. Justifica que essa crise da educação literária é derivada do século XIX. Afirma que "a multiplicidade dos textos, a onipresença das imagens, a variedade das manifestações culturais" (COSSON, 2006, p. 20) são características da sociedade contemporânea. A literatura não se enquadra nesses padrões, por isso a recusa da literatura na educação.

Apesar de a literatura fazer parte da vida das pessoas há muito tempo, a disciplina de Literatura na escola não possui destaque e importância, nos dias de hoje. Cosson (2014) destaca que as razões para esse fato podem estar relacionadas ao uso de livros didáticos pelos professores como único recurso pedagógico e que apresentam somente fragmentos de textos literários.

No entanto, com as novas teorias de ensino de língua centradas em gêneros textuais fez com que estivessem presentes, em manuais, textos fragmentados, adaptados ou agrupados em gêneros, modalidades, contextos culturais e/ou temas que não potencializam a importância do texto literário. Tal concepção de ensino defende que um leitor desenvolve competência em 
leitura por meio de contato com textos diversificados e considera que o texto literário tem caráter artístico e não apresenta regularidades necessárias para servir de modelos para o ensino da escrita.

Outra razão para o esquecimento da literatura na escola é a recusa, por parte dos alunos, da leitura de obras clássicas ou dos cânones. Os argumentos pela negativa é que 0 vocabulário, a sintaxe, o tema e os padrões narrativos são complexos e distantes dos seus interesses. Cosson (2014) ressalta que afirmar que os clássicos têm valor cultural não é argumento suficiente para os jovens se convencerem a realizar a leitura desses textos.

Os professores, na tentativa de diminuir a resistência dos alunos diante da leitura na íntegra do texto literário, defendem a leitura de best-sellers, afirmando que o importante é que leiam, independente da qualidade. Alguns insistem que a leitura dos clássicos é importante e tratam o texto literário como conteúdo com provas, resumos e/ou trabalhos. Assim, os docentes têm o dilema de recomendar a leitura de clássicos ou optar por textos contemporâneos.

A compreensão de que o ensino de literatura possui espaço inadequado na escola por ser considerada uma manifestação cultural, é mais uma razão para o texto literário estar perdendo importância. $O$ autor expõe que, por conta do

argumento da democratização da cultura ou da valorização da diversidade cultural contemporânea, defende-se que as obras literárias representadas pelos livros cedam lugar aos filmes, shows, vídeos, programas televisivos e tudo o mais que compõem 0 cenário atual da vida dos jovens (COSSON, 2014, p. 14).

Os defensores dessa concepção corroboram que a literatura na escola fazia sentido como veículo difusor da cultura, mas que hoje a formação cultural do jovem não prima por esses aspectos, o que torna a literatura dispensável do currículo escolar. Em vista disso, o espaço da literatura e de práticas de leituras está estreitando-se. O saber literário, em consequência, perde sua condição de conhecimento.

Cosson (2014, p. 15) preconiza a importância do resgate da literatura "como palavra qua palavra, independentemente de seu registro ou veículo de transmissão". Com isso, defende que o que está em declínio são as formas que a tradição conhece e valoriza como literárias. Também, acredita que na atualidade a literatura está "experimentando uma nova forma de alargamento ao ser difundida em diferentes formatos e veículos". (COSSON, 2014, p. 15)

Nessa perspectiva, o que 0 autor legitima é que não se deveria identificar determinada obra como literária, mas verificar como a literatura está presente em manifestações que transitam pelo seu espaço discursivo. Na atualidade, as obras se entrecruzam e se constituem sem limites e não são reconhecidas apenas por um traço único, singular. Por conta disso, "0 
trânsito de uma obra a outra, a passagem de um veículo a outro, acontece justamente porque 0 terreno em que eles se movem é comum: o espaço literário". (COSSON, 2014, p. 19)

0 autor ressalta que, com tal particularidade, o texto literário, que está presente em formas e veículos diversificados, não pode ser observado apenas em sua qualidade estética e artística, é preciso identificar de que forma a palavra literária constitui-se no objeto literário. É assim que a literatura se configura nos dias atuais, em suportes que não necessariamente são livros impressos, mas em adaptações para cinema, teatro, histórias em quadrinhos, e-books, vídeos, televisão. Enfim, a literatura permanece enquanto fonte ou referência, segundo Cosson (2014), pois se a sociedade não disponibiliza tempo para realizar leitura contemplativa ou privilegia a visualidade e o movimento como traços preferenciais das manifestações culturais, os textos literários perdem a sua integralidade.

O autor (COSSON, 2014) acrescenta que as obras literárias escritas são lidas pelos jovens, nos dias de hoje, porém com objetivos diferenciados dos preconizados pela escola e valorizados pela elite cultural. E, se não são lidas, estão presentes quando eles a produzem no ato de simulação, vivenciando a narrativa ficcional ao participarem de jogos de personificação ou de RPG. A presença de informações relevantes para a composição da personagem, do cenário e/ou de uma ação do texto literário estão presentes nos manuais dos jogos. Com isso, os jovens vivenciam com mais intensidade a narrativa ficcional do que com a leitura solitária do texto impresso.

Também, a presença da literatura entre os jovens acontece quando incorporam obras ou movimentos literários a seu estilo de vida, como atitudes, caracterizações físicas, idealismos. 0 texto literário, nessa situação, é fonte de ordenamento ou sentido de vida. Assim, Cosson (2014) acredita ser importante discutir o conceito de literatura, para que se solidifiquem a sua circulação e a sua permanência na escola e na sociedade em geral. $O$ início dessa discussão centra-se em conceber que

ler consiste em produzir sentidos por meio de um diálogo, um diálogo que travamos com o passado enquanto experiência do outro, experiência que compartilhamos e pela qual nos inserimos em determinada comunidade de leitores. Entendida dessa forma, a leitura é uma competência individual e social, um processo de produção de sentidos que envolve quatro elementos: 0 leitor, 0 autor, 0 texto e 0 contexto (COSSON, 2014, p. 36)

Destaca que os elementos centrais desse processo estão presentes nas diversas teorias de leitura e de literatura que circulam pela academia. Ressalta que a importância de cada aspecto no ato de ler pode ser diferenciado. Isso modifica o entendimento e a função de cada elemento na leitura. Cosson (2014) enfatiza que o ato de ler é um processo que passa, 
necessariamente, por um leitor, um autor, um texto e um contexto. Se um deles não estiver presente, o circuito não fica completo e o processo apresenta falhas em seu desenvolvimento. Esse diálogo inicia-se com uma indagação, que a leitura responde e sugere nova pergunta; é um movimento que consolida 0 ato de ler.

Tal consolidação pode ser efetivada na escola, que é um lugar de aprendizagens sistemáticas e sistematizadas de leitura. O autor (COSSON, 2014) acredita que ler, na atualidade, é de vital importância porque define quem o ser humano é e o que faz. Para isso, afirma que é preciso ler de maneira formativa para tornar-se um leitor competente e expõe cinco formas de se atingir esse objetivo. A primeira é a leitura de diferentes textos. Ao contatar com estruturas textuais diversificadas, o leitor constrói um repertório que serve de preceito para outras leituras.

A segunda especifica que as pessoas lêem de diferentes modos. Isso implica afirmar que não se lê do mesmo jeito, porque se tem objetivos diferenciados em cada leitura que se faz. Essa diversidade de textos desenvolve a competência em leitura. A terceira determina que se lê para conhecer o texto, pois o leitor é desafiado a responder a uma demanda específica. A escolha por uma determinada leitura está relacionada com o desejo ou com a necessidade de conhecimento, entendimento e/ou vivência. A somatória de leituras é a motivação para o leitor constituir sua história de vida e sua história de leitor.

A quarta forma aponta para a avaliação que o leitor realiza após a leitura. Os critérios são a identificação da carga ideológica que o texto apresenta, a distinção se valeu a pena ter realizado a leitura e que aspectos são importantes de serem destacados. A quinta define que 0 leitor lê para aprender a ler. As habilidades desenvolvidas, durante esse processo, permitem ao leitor, além de conhecer e controlar seus mecanismos de leitura, aprimorá-los. A continuidade do exercício amplia a competência do leitor.

0 autor ressalta que a leitura formativa efetiva-se, realmente, na literatura, uma vez que o leitor tem "acesso a uma grande diversidade de textos, pois é próprio do discurso literário a multiplicidade de formas e a pluralidade dos temas" (COSSON, 2014, p. 49). Tal diversidade permite o desenvolvimento de diferentes modos de ler, tendo em vista que a literatura incorpora diversificados discursos e estruturas textuais de uma sociedade. Permite, ainda, ao leitor escolhas condizentes com sua capacidade de compreensão do discurso literário.

A leitura da literatura permite o contato com outros caminhos de vida, possibilitando a construção da identidade do leitor, que ao assumir a posição de sujeito consegue realizar criticidade em relação ao modo de dizer e ao que é dito. Ainda, a leitura literária proporciona a 
experiência de romper limites espaciais e temporais. Cosson (2014) reforça que a literatura é formativa, porque forma leitores e sujeitos da própria leitura.

A leitura entendida como diálogo pressupõe uma relação que se estabelece entre leitor e autor, texto e contexto, constituindo o que Cosson (2014) denomina de circuito da leitura. A indispensável relação entre esses quatro elementos consolida 0 ato de ler enquanto processo cognitivo e simultaneamente social. O diálogo é mediado por três objetos da leitura, que são: 0 texto, o contexto e o intertexto. Ao realizar a leitura, o leitor contata com tais objetos e cabe a ele enfatizar um deles ou todos.

O texto, um dos elementos do circuito da leitura, é concebido enquanto materialidade física e com o fazer que o constitui. Ainda, Cosson (2014) defende que o texto pode ser considerado como tal somente após passar pelos olhos e pelas mãos do leitor. Em se tratando do texto literário, o autor afirma que seu discurso é complexo e multifacetado. As formas de identificar o discurso literário estão centradas no leitor e na literariedade. No primeiro, a experiência da leitura é constituidora do literário e cabe ao leitor processar o texto. No segundo, os elementos estilístico/linguísticos distinguem o texto literário do não literário. Então, está centrado no leitor o papel fundamental de identificação e de reconhecimento do literário.

Outro elemento é o contexto, que é constituído por dados históricos e listagem de traços estilísticos. Também, Cosson (2014) destaca outros pontos que auxiliam em sua definição: 0 ponto local e o ponto global. Um corresponde à interação entre texto e contexto. 0 outro referese às condições sociais e culturais em que a interação acontece. Ainda, para definir contexto, Cosson (2014) expõe que é importante acrescentar o campo do letramento. Isso, porque ele abarca três aspectos: o contexto com-o-texto (elementos intratextuais e textuais de uma obra), 0 contexto ao-redor-do-texto (condições imediatas que envolvem o processamento da obra) e 0 contexto além-do-texto (condições culturais e sociais de produção e recepção de obras).

0 intertexto é o terceiro elemento que compõe o circuito da leitura. Refere-se à relação entre textos, ou seja, um texto sempre dialoga com outros textos. Enquanto objeto da leitura literária, Cosson (2014) ressalta que o intertexto possui estatuto diferenciado, uma vez que por meio dele se verifica que não apenas o "texto ou os textos que estão entretecidos em um determinado texto, mas também se evidenciam as relações que se estabelecem entre os elementos e os objetos da leitura" (COSSON, 2014, p. 60).

Há que se destacar, ainda, em relação ao intertexto, que ele apresenta três núcleos de sentido na leitura. 0 primeiro está ligado ao autor como leitor, pois, nessa perspectiva, 0 autor reescreve as suas leituras em um novo texto. $O$ segundo está relacionado à trama do texto. Isso implica afirmar que há a presença de um texto na elaboração de outro texto. 0 terceiro é Revista de Ciências Humanas, Frederico Westphalen - RS, v. 22, n.2, p. 96-115, maio/ago. 2021. 
composto pela relação contextual do leitor com a obra. Nesse elemento, o intertexto é criado pelo leitor ao associar dois textos. É o leitor que negocia o sentido da obra e constrói os sentidos dos textos.

Em vista disso, os modos de leitura, então, passam por quatro elementos: leitor, autor, texto e contexto; e, por três objetos: texto, contexto e intertexto. Tais aspectos constituem 0 diálogo da leitura. $\mathrm{O}$ autor especifica que um objeto visto de um ponto de vista determina o modo de ler. Por isso, explica que "para cada um dos três objetos quatro modos de ler" (COSSON, 2014, p. 71). Realiza uma soma e afirma que há "doze modos distintos de ler a obra literária" (COSSON, 2014, p. 71).

\section{ESTÉTICA DA RECEPÇÃO: LEITOR-TEXTO-TEXTO-LEITOR}

A teoria da Estética da Recepção surgiu nos anos 60, em um contexto sinalizado pelo questionamento do paradigma dominante do estruturalismo e se tornou uma teoria da comunicação literária. Tendo como principais nomes os autores Hans Robert Jauss (1921-1997) e Wolfgang Iser (1926-2007), conhecidos por ter reformulado o conceito de Estética da Recepção, desenvolvendo a noção dinâmica do leitor, ouvinte ou espectador como fator essencial à constituição de sentido à obra. $O$ marco inicial dessa teoria acontece em 1967, com base na aula inaugural de Hans Robert Jauss na Universidade de Konstanz intitulada O que é e com que fim se estuda a história da Literatura, publicada, posteriormente, em 1994, com o título A história da literatura como provocação à ciência da literatura.

Os estudos de Jauss se iniciavam com questões polêmicas, haja vista que esclarecia em seu texto que o objetivo de suas pesquisas era propor novos rumos para o estudo da literatura, contemplando novos elementos, pois, de acordo com ele, "a história da literatura vem, em nossa época, cada vez mais mal afamada - e, aliás, não de forma imerecida. Nos últimos 150 anos, a história dessa venerável disciplina tem inequivocadamente trilhado o caminho da decadência constante" (JAUSS, 1994, p. 5).

\footnotetext{
Jauss, com seu programa de reabilitar metodologicamente os estudos de história da literatura, transformando-a no fundamento para a formulação de uma teoria literária eqüidistante do estruturalismo e do marxismo, encontra em Gadamer um de seus principais guias e modelos. Como o mestre, recupera a história como base do conhecimento do texto; e, igual ao outro, pesquisa seu caminho por um via que permite trazer de volta 0 intérprete ou o leitor, seus defesa predileta na luta intelectual contra as correntes teóricas indesejadas (JAUUS; GADAMER, 1989, p. 12).
} 
Nesse viés, a Estética da Recepção contrapõe-se a outras correntes teóricas, tais como: teóricas marxista e formalista, crítica sociológica, o new criticism, o formalismo russo e 0 estruturalismo, tendo em vista que estas só se preocupavam com as obras e os seus autores, não se importando com o leitor, terceiro elemento da construção literária que ficava à margem. $A$ crítica à teoria literária marxista consiste no fato de entender como sendo seu papel expor a literatura como reação dos fenômenos sociais, o que emite um juízo de valor de uma obra literária pautado em sua capacidade de representação da estrutura social. Quanto à teoria literária formalista, a crítica fundamenta-se na concepção da obra literária como autônoma, independente de dados históricos ou biográficos do autor, atribuindo a verdadeira significação a sua organização interna sem observar as situações externas da criação.

Assim, os estudos propostos por Jauss manifestaram que o leitor é o terceiro e um dos principais elementos da trama literária, ele tem o papel de coprodutor de significações e é através da sua recepção durante a leitura que são ativadas implicações inerentes aos seus conhecimentos prévios e a leitura realizada. Como uma atividade que é direcionada pelo texto, a leitura une o texto aos efeitos tidos com o leitor, influência chama por Iser (1979, p. 83) de "interação". Ainda, o autor disserta que a "interação não é um dom da natureza, mas sempre o produto de uma atividade interpretativa, de que se origina uma imagem do outro, que é, simultaneamente, uma imagem de mim mesmo." (ISER, 1979, p. 87).

Face à elaboração da teoria da Estética da recepção, Jauss aprofunda-se em seus estudos e passa a analisar o Horizonte de Expectativa, com base na necessidade do trabalho do texto literário em sala de aula, item que focaliza a formação do leitor, do espectador no contexto do ensino e passa a não corroborar com o vazio existente entre a literatura e a história. Para 0 autor, qualquer produto precisa de um destinatário que lhe dê significações, sentidos - leitores com diferentes contextos, visões, experiências e culturas -, que defronte com a obra e manifeste a diversidade dialógica existente entre literatura e leitor.

\footnotetext{
A obra que surge não se apresenta como novidade absoluta num espaço vazio, mas, por intermédio de avisos, sinais visíveis e invisíveis, traços familiares ou indicações implícitas, predispõe seu público para recebê-la de uma maneira bastante definida. Ela desperta a lembrança do já lido, enseja logo de início expectativas quanto a "meio e fim", conduz o leitor a determinada postura emocional e, com tudo isso, antecipa um horizonte geral da compreensão vinculado, ao qual se pode, então - e não antes disso -, colocar a questão acerca da subjetividade da interpretação e do gosto dos diversos leitores ou camadas de leitores. (JAUSS, 1994, p.28)
}

Diante disso, o Horizonte de Expectativa é abrangente, pois, inicialmente, é observado como o limite do que pode ser visível, sujeito às mudanças de perspectivas do leitor. 0 diálogo 
entre obra e leitor proposto por Jauss não permite somente examinar a imagem e a influencia do autor através da história, mas, também, possibilita compreender as condições históricas e as variações do seu entendimento.

Observar o título de obra e criar expectativas sobre o que será lido é um dos principais pontos do horizonte de expectativa, tendo em vista que momento em que o leitor irá supor personagens, histórias, acontecimentos, lugares etc. Essa construção implica, também, e, principalmente, nas leituras anteriores realizadas por esse expectador que, de certa forma, "preenche as entrelinhas" do título da obra com suas concepções e experiências leitoras, introduzindo múltiplas possibilidades interpretativas. À propósito,

\begin{abstract}
A obra que surge não se apresenta como novidade absoluta num espaço vazio, mas, por intermédio de avisos, sinais visíveis e invisíveis, traços familiares ou indicações implícitas, predispõe seu público para recebê-la de uma maneira bastante definida. Ela desperta a lembrança do já lido, enseja logo de início expectativas quanto a "meio e fim", conduz o leitor a determinada postura emocional e, com tudo isso, antecipa um horizonte geral da compreensão vinculado, ao qual se pode, então - e não antes disso -, colocar a questão acerca da subjetividade da interpretação e do gosto dos diversos leitores ou camadas de leitores. (JAUSS, 1994, p.28)
\end{abstract}

Pautando-se nesses pressupostos, ressalta-se, que o horizonte de expectativas, além de expor a visualização inicial do leitor perante a obra, verifica como a obra prenuncia a participação do leitor. A elaboração de uma obra literária é pautada com uma intenção, seja ela impactante, emocionante etc. Logo, o autor antecipa reações mediante a obra que nem sempre serão correspondidas, haja vista que nem sempre aquela situação irá dialogar plenamente com 0 contexto atual do leitor. A obra prevê, portanto, de acordo com Jauss (1994), um sistema de expectativas psicológicas, culturais e históricas por parte do receptor. Com isso, percebe-se quem nem o autor e nem o leitor aproximara-se de tal obra sem alguma intenção ou suposição de acontecimentos, toda aproximação é intencional, está relacionada com as expectativas e cada um.

\title{
4 ANÁLISE DO CONTO “ARDENTE AMOR"
}

O conto "Ardente amor", do autor gaúcho Roberto Bittencourt Martins, publicado em 1997, conta a história de Turíbio Vaz e Ondina Menezes, ocorrida nas cidades de Livramento e Bagé, Rio Grande do Sul. Narrado em terceira pessoa, o conto tem como objetivo relatar acontecimentos que norteiam o amor como uma dualidade contraditória entre duas pessoas, 
com a utilização de um poema clássico para confirmação e justificativa de um amor "ardente", o soneto de Luíz Vaz de Camões, "Amor é fogo que arde sem se ver".

Inicialmente, ao ler o título do conto, é possível criar suposições e inúmeras expectativas, tendo em vista a teoria que embasa este trabalho, Estética da Recepção, que permite, através do Horizonte de Expectativas, ler, somente diante do título do texto, possibilidades de enredo, personagens, temáticas etc. Neste caso, o título do conto apresentado com uma função poética e com a inserção do adjetivo anteposto, o que prenuncia 0 fogo, a chama - deixa explícito que será uma narrativa sobre amor muito forte, que, provavelmente, haverá chamas emocionais ou físicas, mas sem detalhamentos sobre entre quem será este amor, quantas pessoas estarão envolvidas e nem seu possível clímax. Logo, o leitor é responsável por essa leitura, havendo, portanto, conforme Iser (1979), a interação entre leitor-obra.

O desenrolar da trama se inicia em um teatro da cidade de Bagé que pega fogo durante a declamação do poema de Camões, interpretado por uma atriz em homenagem a uma colunista, "Espavorida, a mulher disparou cenário adentro, deixando interrompida a indagação arrevesada do poema: mas como causar pode seu favor nos corações humanos...?" (MARTINS, 1997, p. 8). Primeira exposição do poema de Camões no conto, o que permite que o leitor tenha um primeiro contato com uma diferente narração no texto, versos, cuja apresentação percebe-se a intertextualidade proposta por Jenny.

Em seguida, enquanto todos saíram do ambiente, Turíbio "conservou sangue-frio" (ibidem, p. 9) e avistou Ondina em chamas. Ao salvá-la, o rapaz fica conhecido como herói por todos e passa alguns dias internados no hospital, momento que somente as visitas de Ondina Ihe traziam alegria e "suspeitava que eram as visitas da amada que restauravam sua saúde [...] sentia uma alegria estranha, felicidade e aflição" (ibidem, p.10).

Turíbio, por ser um rapaz simples e de origem humilde, pode ser visto, como uma espécie de herói legítimo, homem de caráter, e de muitos sentimentos, não aceita, imediatamente, a recompensa oferecida pelos irmãos da moça, mas, aos repensar sua situação "sem instrução, órfão de pai e mãe" (ibidem, p. 11), ele aceita o dinheiro oferecido. Após um tempo, passa a morar em uma pensão oferecida por seu primo e a trabalhar em uma venda da cidade. Aparentemente Turíbio estava bem, mas não esquecida de sua amada, Ondina.

Os negócios estavam bons e o rapaz, depois de descobrir que Ondina iria embora, resolve ir atrás da moça, Turíbio viaja a Bagé. Chegando a sua cidade de origem, ele avista a moça "luminosa, rodeada por dois rapazes [...] Felizmente o noite não a acompanhava, talvez estivesse distante. Aguardou, ansioso, o final da missa" (ibidem, p. 20). Ao chegar próximo a 
Ondina, ao final da missa, Turíbio se emociona com a doçura da moça e diz que "depois do incêndio, ele mesmo se consumira em chamas [...] Ela não compreendeu, mas ele explicou: do fogo do teatro, sim, mas não da fogueira do amor que passara a arder por ela" (ibidem, p. 21), revelando, neste episódio, o segundo sentido do adjetivo "ardente" no título, inicialmente o fogo físico e agora o emocional, o amor que o consumia, o que permite ao leitor uma relação com a obra.

Ondina tenta fugir, diz que não pode corresponder ao seu amor, pois irá se casar. Turíbio insiste e segura seu braço, causando uma confusão. O rapaz é levado à prisão da cidade pelos irmãos da moça e, após uma noite preso, é solto para retornar a sua cidade, sob a condição de nunca mais procurar Ondina. Triste e com receio da moça odiá-lo, Turíbio volta a Livramento e sem demora, mesmo com as lembranças que o entristecia, casa-se e constrói uma família com uma moça da quadrinha, "teve filhos, trabalhou, criou seu próprio negócio, tornou-se uma pessoa influente, nas duas cidades gêmeas e acabou sendo eleito Presidente da Associação Comercial. Nessas funções, foi chamado para participar de uma importante reunião em Bagé" (ibidem, p. 29).

Chegou a Bagé com um sentimento estranho "era sua terra, mas tudo nela the era estranho" (ibidem, p. 30). Durante o jantar, conhece o velho coronel da cidade, Alcade, a quem todos cumprimentavam com respeito e que havia salvo a vida de Turíbio dos irmão Menezes, irmão de Ondina, no dia em que haviam o prendido, tendo em vista que a intenção da família da moça era matar Turíbio. O rapaz agradece, novamente, o que o delegado havia feito por ele anos atrás e, após um tempo de diálogo, o coronel indaga-o "Turíbio de certo sabia que Ondina casara mesmo com o noivo?" (ibidem, p. 31) e continuou "Casara, mas nunca tivera filhos, e, na Revolução de 23, perdera o marido e o irmão Chico... ficara viúva por um ano, falecera em seguida" (ibidem, p. 31).

Turíbio fica espantado, porém "lutando contra a emoção, faz um comentário informal e fingiu-se ocupar com o prato" (ibidem, p. 31). E, neste instante, o coronel passa a revelar toda a história de Ondina e de Turíbio,

\footnotetext{
na verdade, fora Chico Menezes quem proibira a irmã de visitar Turíbio, depois que a supreendera beijando o rapaz na fronte durante a ausência da freira... Turíbio estremeceu [...] Ondina havia ameaçado não se casar se a vida de Turíbio não fosse poupada. Ondina vivera solitária, reclusa em sua própria casa, como uma prisioneira... pensava-se que seria tristeza pelas mortes do marido e do irmão... adoecera, ardera em febre, morera de tuberculose galopante... dentro da família, como agora sabia, ficara a lenda de que ela havia morrido de amor... um desses amores que, em vez de trazem alegria, levam só as tristezas [...] ao morrer, Ondia faz um pedido à cunhada confidente... queria uns versos inscritos numa placa em sua sepultura... a família cumpre a promessa (ibidem, p. 33).
} 
Turíbio, ao ouvir a história, sente-se desolado. O jantar estava terminando e o rapaz, quase em jejum, levanta-se contendo suas emoções e diz ao delegado que tudo era passado, que não havia mais importância. Ao sair, olha nos olhos do delegado e percebe um brilho estranho, como se ainda restassem palavras que não foram ditas. Passou a noite acordado, pensado em Ondina e em tudo que o coronel havia contado. No dia seguinte, comprou rosas vermelhas e seguiu até o cemitério.

\begin{abstract}
Lá estava o jazigo: o nome no mármore branco, as datas do princípio e do fim. E, numa placa de bronze, as letras gastas, os versos. Foi lendo as palavras em voz alta até as últimas linhas: "Amor é fogo que arde sem se ver; É ferida que dói e não se sente; É um contentamento descontente; É dor que desatina sem doer; É um não querer mais que bem querer; É solitário andar por entre a gente; É nunca contentarse de contente; É cuidar que se ganha em se perder; É querer estar preso por vontade; É servir a quem vence, o vencedor; É ter com quem nos mata lealdade" (ibidem, p. 35).
\end{abstract}

Turíbio fica sem voz, sem reação e "num clarão repentino, percebeu o clarão intrigante no olhar do velho Alcalde. Ali estava o que não fora dito, que somente ele poderia entender" (ibidem, p. 35), os últimos versos do soneto de Camões, "Mas como causar pode seu favor, Nos corações humanos amizade, Se tão contrário a si é o mesmo Amor?"( ibidem, p. 35). Ali estava a mensagem que Ondina deixara para ele, o poema que estava sendo declamado na noite em que se conheceram. O rapaz, naquele momento, quase podia ouvir a voz de sua amada. Beijou 0 mármore e saiu, levando em seu pensamento e em seu coração as lembranças e a certeza que agora Ondina podia acompanha-lo, "unida a ele para sempre, compartilhando, invisível, as chamas do mesmo amor" (ibidem, p. 37).

Com base nessas colocações sobre 0 texto, observa-se que a construção composicional do conto "Ardente amor" é composta por discursos em prosa e em verso, tendo em vista a utilização do soneto para legitimar as ações de Turíbio Vaz. Assim, percebe-se, que ao final de cada etapa da narrativa as atitudes e os sentimentos do personagem são justificadas com excertos de "Amor é fogo que arde sem se ver", uma espécie de metáfora para as passagens, fazendo com que o leitor interaja com o conto e identifique a intertextualidade explícita - versos do poema - no texto. (JENNY, 1997).

\title{
CONSIDERAÇÕES FINAIS
}


A teoria da Estética da Recepção oportuniza que o leitor dialogue com o texto e construa novos sentidos ao que se lê. Dessa forma, nota-se a sua relevância enquanto base para a formação de leitores críticos e proficientes, haja vista que criar novos sentidos a uma obra propõe muito além de novas significações, mas sim de trabalhar com o texto em relação ao contexto dos alunos e aos diversos contextos que a sociedade propõe. A linha tênue existente entre 0 texto e o leitor é o que reitera os novos perfis leitores existentes e suas inúmeras inferências (SANTAELLA, 2015).

As perspectivas da leitura literária, quando centradas no autor, como proposto neste trabalho, a partir de uma leitura reflexivo-crítica acerta dos leitores e suas infinitas possibilidades de leitura, no contexto e no intertexto, é uma maneira efetiva de incentivar a leitura, a escrita e a interpretação nas diversas faixas etárias e preferências leitoras. Portanto, a leitura do conto é realizada, conforme Jauss (1994), diante das expectativas que o leitor prenuncia e que serão ou não visualizadas, o que favorece a visualização da intertextualidade e da contextualização leitora, em que a literatura passa a compreendida, sobretudo, enquanto um mosaico de linguagens, interpretações e ressignificações.

O conto "Ardente amor", ao dialogar com o poema, possibilita, através da intertextualidade e do horizonte de expectativas, novas possibilidades de compreensão e assimilação da temática e dos acontecimentos do conto. Logo, reitera-se que o leitor tem papel fundamental na construção interpretativa do texto, haja vista que é através dos conhecimentos e dos textos anteriores que o leitor possui, que as conclusões, expectativas e suposições da narrativa são reconstituídas. Esse fator é salientado, uma vez que a narrativa pressupõe, além da intertextualidade explícita, nuances da construção estilística do texto que incentivam ao leitor contemporâneo a realização de novos parâmetros literários.

Verificou-se, também, que conto selecionado aponta que novas perspectivas de leitura e de novos horizontes de expectativa que instigam o leitor a interagir com a trama. Diante de sua temática, por utilizar de dois tipos de discursos, prosa e verso, por exemplo, o texto, dispõe da diversidade das construções textuais e as suas infinitas interpretações e reconstruções, característica que permite a contextualização e o cotejo da obra, trazendo a contemporaneidade do texto para as novas gerações leitores juvenis. Essa peculiaridade da obra corrobora com uma exploração dialógica entre o leitor e o conto, o que reitera a concepção de novos sentidos ao que se lê (COLOMER, 2003).

\section{REFERÊNCIAS}

Revista de Ciências Humanas, Frederico Westphalen - RS, v. 22, n.2, p. 96-115, maio/ago. 2021.

\begin{tabular}{l|l} 
Recebido em: 20/05/2021 & Aceito em: 21/06/2021
\end{tabular} 
COLOMER, Teresa. A formação do leitor literário. São Paulo: Global, 2003.

COSSON, Rildo. Letramento literário: teoria e prática. São Paulo: Contexto, 2006.

COSSON, Rildo. Círculos de leitura e letramento literário. São Paulo: Contexto, 2014.

ISER, Wolfgang. A interação do texto com o leitor. In: JAUSS, Hans Roberto et al. A literatura e o texto: textos da estética da recepção. Traduzido por Luiz Costa Lima. Rio de Janeiro: Paz e terra, 1979.

JAUSS, Hans Robert. A história da literatura como provocação à teoria literária. São Paulo: Ática, 1994.

GADAMER, Hans-George. A estética da recepção no horizonte dos 60 anos. In: ZILBERMAN, Regina. Estética da recepção e história da literatura. São Paulo: Editora Ática, 1989.

JENNY, Laurent. A estratégia da forma. In: Intertextualidades. Tradução da revista

Poétique número 27. Lisboa: Almedina, 1997.

KRISTEVA, Julia. Introdução à semanálise. Trad. Lúcia HelenaFrança Ferraz. 2. ed. São Paulo: Perspectiva, 2005.

MARTINS, Roberto Bittencourt. Ardente amor. In: Ardente amor \& outras histórias. Porto Alegre: Mercado Aberto, 1997.

SANTAELLA, Lúcia. Comunicação ubíqua: repercussões na cultura e na educação. São Paulo: Paulus, 2013.

SANTAELLA, Lúcia. Navegar no ciberespaço: o perfil cognitivo do leitor imersivo. 5. ed. São Paulo: Paullus, 2015. 